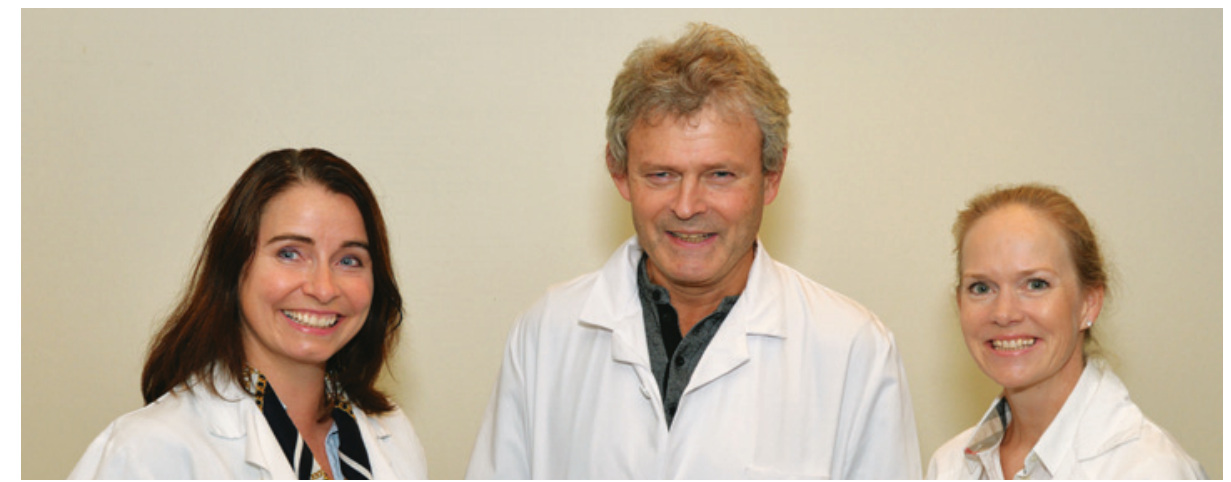

Kardiologene Janne Mykland og Kjetil Steine og lungelege Ingunn Skjørten. Foto: Einar Stranden

\title{
Hjertepatologi hos kolspasienter utvikles tidlig
}

\author{
Selv pasienter med moderat kronisk obstruktiv lungesykdom og normalt \\ lungearterietrykk har patologiske forandringer i høyre ventrikkel.
}

Utvikling av høyt blodtrykk i lungekretsløpet er en fryktet komplikasjon hos pasienter med kronisk obstruktiv lungesykdom (kols). Høyt trykk i lungekretsløpet kan påvirke hjertets høyre ventrikkel negativt inntil cor pulmonale oppstår. En gruppe norske leger har undersøkt høyresidig hjertefunksjon hos kolspasienter med normalt lungearterietrykk (1).

Studien omfattet 98 kolspasienter og 34 kontrollpersoner med tilsvarende alder og kjønn. Alle kolspasientene fikk utført høyresidig hjertekateterisering, og begge gruppene fikk undersøkt hjertet med ultralyd (vevsdoppler). Høyre ventrikkels veggtykkelse og størrelse ble målt med todimensjonal ekkokardiografi.

Kolspasientene med normalt lungearterietrykk (gjennomsnittlig pulmonalt arterietrykk $(\mathrm{mPAP}) \leq 20 \mathrm{~mm} \mathrm{Hg}$ ) hadde signifikant tykkere vegger og større høyre ventrikler enn kontrollpersonene, også etter eksklusjon av dem med grensesignifikant økt lungearterietrykk (mPAP 21-24 mm $\mathrm{Hg}$ ). Tilsvarende var systolisk funksjon for høyre ventrikkel ved tre nye ekkoindekser signifikant lavere hos kolspasientene enn hos kontrollpersonene. Forskjellene mellom høyre ventrikkels funksjon og remodellering hos kolspasientene med normalt lungearterietrykk og dem med patologisk økt lungearterietrykk (mPAP $\geq 25 \mathrm{~mm} \mathrm{Hg}$ ) var signifikant, men klart mindre. Studien viser at nedsatt funksjon, økt veggtykkelse og størrelse av høyre ventrikkel er til stede selv ved en liten økning i lungearterietrykket hos pasienter som har moderat kols.

- Denne studien viser at det er patologiske forandringer i høyre ventrikkel før det har utviklet seg patologisk økt trykk i lungekretsløpet, sier Janne Mykland Hilde, som er kardiolog ved Akershus universitets- sykehus og førsteforfatter av artikkelen. - Vi anbefaler derfor at det diagnostiske begrepet cor pulmonale revurderes.

- Denne studien tyder på at intervensjon og behandling bør startes på et tidligere stadium ved kols enn det som har vært vanlig til nå. Det viktigste tiltaket er å få pasientene til å slutte å røyke, og leger bør være enda tydeligere på dette overfor pasientene tidlig i sykdomsforløpet, sier Hilde.

\section{Klinikere med interesse for forskning}

Forskningsgruppen bak denne studien består av kardiologer og lungeleger som tidligere arbeidet ved Aker sykehus under ledelse av Kjetil Steine og Sjur Humerfelt. Stipendiatene Janne Mykland Hilde, som nå er kardiolog ved Akershus universitetssykehus, og Ingunn Skjørten gjennomførte de praktiske undersøkelsene av pasientene, som ble rekruttert av de deltakende lungelegene. Studien er finansiert av Helse SørØst og Ekstrastiftelsen. Gruppen har hatt et utstrakt samarbeid med radiologisk avdeling og geriatrisk avdeling ved Oslo universitetssykehus, Aker og Ullevål.

Medforfattere er lungelege Ingunn Skjørten, intervensjonsradiolog Ole Jørgen Grøtta, kardiolog Viggo Hansteen, lungelege Morten Nissen Melsom, fysiolog Jonny Hisdal, lungelege Sjur Humerfelt og kardiolog Kjetil Steine.

\section{Matilde Risopatron Berg}

matilde.risopatron.berg@legeforeningen.no Tidsskriftet

\section{Litteratur}

1. Hilde JM, Skjørten I, Grøtta OJ et al. Right ventricular dysfunction and remodeling in chronic obstructive pulmonary disease without pulmonary hypertension. J Am Coll Cardiol 2013; 62: 1103-11.
Ordforklaringer

mPAP: Gjennomsnittlig pulmonalt arterietrykk Måles ved høyresidig hjertekateterisering. Verdier over $25 \mathrm{~mm} \mathrm{Hg}$ er definert som patologiske.

Vevsdoppler: Ultralydmetode som måler lokale hastigheter i hjertemuskulaturen.

Cor pulmonale: Høyresidig hjertesvikt som resultat av økt trykk i pulmonalarteriene hos pasienter med lungesykdom.
Artikkelen ble publisert 17. september 2013 i Journal of the American College of Cardiology, som er et av de høyest rangerte kardiologiske tidsskriftene 